\title{
Penentuan konsentrasi stainless steel 316L dan kobalt kromium remanium GM-800 pada uji GPMT
}

\author{
Ikmal Hafizi*, W. Widjijono**, Marsetyawan Heparis Nur Ekandaru Soesatyo*** \\ *Pascasarjana Fakultas Kedokteran Gigi, Universitas Gadjah Mada, Yogyakarta, Indonesia \\ **Departemen Biomaterial, Fakultas Kedokteran Gigi, Universitas Gadjah Mada, Yogyakarta, Indonesia \\ ***Departemen Histologi dan Biologi Sel, Fakultas Kedokteran, Universitas Gadjah Mada, Yogyakarta, Indonesia \\ *JI Denta No 1 Sekip Utara, Yogyakarta, Indonesia; e-mail: ikmal.fkg@gmail.com
}

Submisi: 27 Mei 2016; Penerimaan: 8 Juni 2016

\begin{abstract}
ABSTRAK
Dunia kedokteran gigi banyak menggunakan logam pada pembedahan maxillofacial, cardiovascular, dan sebagai material dental. Logam yang banyak digunakan antara lain adalah kobalt kromium dan stainless steel. Stainless steel 316 merupakan austenistic stainless steel yang memiliki komposisi karbon rendah sehingga dapat meningkatkan ketahanan terhadap korosi sama halnya dengan kandungan molybdenum pada material tersebut. Kobalt kromium (CoCr) adalah cobalt-based alloy dengan campuran chromium. Kepadatan (density) dari logam campur kobalt kromium adalah sekitar 8-9 gram $/ \mathrm{cm}^{3}$ menyebabkan logam campur ini relatif sangat ringan. Remanium GM-800 merupakan salah satu jenis alloy kobalt kromium dengan kelebihan memiliki resistensi terhadap fraktur yang tinggi serta modulus elastisitas yang tinggi. Penelitian ini bertujuan untuk mengetahui konsentrasi tepat yang digunakan pada stainless steel 316 L dan kobalt kromium GM-800 sebagai bahan uji GPMT. Subjek penelitian adalah kobalt kromium Remanium GM800 dan stainless steel 316 L konsentrasi 5\%, 10\%, 20\%, 40\%, dan 80\%. Patch berisi pasta stainless steel atau kobalt kromium ditempelkan selama 24 jam masing-masing pada 3 hewan coba, selanjutnya dilakukan observasi eritema dan edema dengan menggunakan skala Magnusson dan Kligman. Pada penelitian, konsentrasi $5 \%$ merupakan konsentrasi yang direkomendasikan untuk stainless steel $316 \mathrm{~L}$ dan kobalt kromium GM-800 sebagai konsentrasi tahap challenge uji GPMT, sedangkan konsentrasi $40 \%$ merupakan konsentrasi yang direkomendasikan untuk logam stainless steel $316 \mathrm{~L}$ dan kobalt kromium GM-800 tahap induksi.
\end{abstract}

Kata kunci: GPMT, hipersensitivitas tipe IV, kobalt kromium GM-800, stainless stee/ 316L

\begin{abstract}
Concentration determination of stainless steel 316L and cobalt chromium remanium GM - 800 on GPMT test. Dentistry had used metals such as cobalt chromium and stainless steel in maxillofacial surgery, cardiovascular, and as a dental material. $316 \mathrm{~L}$ stainless steel is austenistic stainless steel which has low carbon composition to improve the corrosion resistance as well as the content of molybdenum in the material. Cobalt chromium (CoCr) is a cobaltbased alloy with a mixture of chromium. Density of a metal cobalt chromium alloy is about 8-9 $\mathrm{g} / \mathrm{cm} 3$ that caused metal interference relatively mild. Remanium GM-800 is one type of a cobalt chromium alloy with the advantages of having high resistance to fracture and high modulus of elasticity. This study aims to determine the exact concentration used in $316 \mathrm{~L}$ stainless steel and cobalt chromium GM-800 as the GPMT test material. Subjects were cobalt chromium Remanium GM-800 and $316 \mathrm{~L}$ stainless steel concentration of $5 \%, 10 \%, 20 \%, 40 \%$ and $80 \%$. Patch containing stainless steel or cobalt chromium paste was affixed for 24 hours each on three experimental animals, then the erythema and edema were observed using the Magnusson and Kligman scale. In the study, concentration of 5\% is the concentration recommended for stainless steel $316 \mathrm{~L}$ and cobalt chromium GM-800 as material in challenge phase GPMT test, while the concentration of $40 \%$ is the concentration recommended for stainless steel $316 \mathrm{~L}$ and cobalt chromium $G M-800$ in the induction phase.
\end{abstract}

Keywords: GPMT, type IV of hypersensitivity, cobalt chromium GM-800, stainless steel 316L

\section{PENDAHULUAN}

Logam merupakan material yang umum digunakan untuk fiksasi tulang. Mulai dari hal sederhana seperti kawat dan sekrup untuk pelat yang bebas dari patah hingga total joint prostheses (tulang sendi buatan) untuk pangkal paha, lutut, bahu maupun pergelangan tangan. Dalam dunia kedokteran logam banyak digunakan pada pembedahan maxillofacial, cardiovascular, dan sebagai material dental. Logam yang banyak digunakan antara lain adalah kobalt kromium dan stainless steel. ${ }^{1}$

Stainless steel merupakan steel alloy dengan penambahan kromium yang membuat sifat bahan tersebut menjadi tahan terhadap karat (stainless). ${ }^{2}$ 
Tipe austenitic stainless steel merupakan jenis stainless steel paling banyak digunakan di Kedokteran Gigi, karena sangat resisten terhadap tarnish dan korosi. ${ }^{3}$ Stainless steel $316 \mathrm{~L}$ merupakan austenistic stainless steel yang berasal dari logam campur SS CrNiMo. Material tersebut memiliki komposisi karbon rendah sehingga dapat meningkatkan ketahanan terhadap korosi sama halnya dengan kandungan molybdenum pada material tersebut. ${ }^{4}$ Paduan logam kobalt kromium molybdenum telah lama digunakan di dalam dunia kedokteran antara lain sebagai material dental prosthesis dan implan karena sifatnya yang kuat, tahan terhadap pemakaian dan mudah dipoles. Logam ini telah dilaporkan berpengaruh dalam perubahan sistem imun di dalam tubuh. ${ }^{5}$ Remanium GM 800 merupakan salah satu jenis alloy kobalt kromium yang sering dipakai sebagai logam tuang dalam pembuatan gigi tiruan sebagian dengan kelebihan memiliki resistensi terhadap fraktur yang tinggi serta modulus elastisitas yang tinggi. ${ }^{6}$

Secara alamiah, hampir semua logam akan mengalami proses korosi sebagai suatu reaksi elektrokimia dalam rangka mencapai kesetimbangan termodinamika. Efek yang kurang menguntungkan dari proses korosi adalah terlepasnya ion-ion logam. ${ }^{7}$ lon logam yang terlepas akan bebas dan dapat menimbulkan toksisitas melalui mekanisme mempengaruhi enzimatik sel atau toksis secara langsung melalui infiltrasi membran. ${ }^{8}$ Material yang akan berkontak langsung dengan tubuh manusia harus memiliki sifat dapat diterima oleh tubuh (biokompatibel). ISO 10993 mengklasifikasikan miniplat sebagai produk kesehatan (health care products) yang berkontak dengan mukosa dalam jangka yang lama. Salah satu uji yang dilakukan pada uji biokompatibilitas adalah uji sensitisasi yang berfungsi untuk menguji hipersensitivitas tipe IV. ${ }^{9}$

Hipersensitivitas tipe IV merupakan salah satu manifestasi dari cell-mediated immunity akibat paparan antigen yang menyebabkan respon berupa perekrutan sel-sel imun. ${ }^{10}$ Uji sensitisasi merupakan uji yang dilakukan untuk mengetahui sifat suatu material dapat menimbulkan reaksi alergi. Salah satu uji yang banyak dilakukan adalah Guinea Pig
Maximization Test (GPMT) yang menggunakan marmut sebagai hewan coba. ${ }^{11}$

Stainless steel merupakan steel alloy dengan penambahan kromium yang membuat sifat bahan tersebut menjadi tahan terhadap karat (stainless). ${ }^{2}$ Stainless steel berdasarkan komposisinya, AISI (American Iron \& Steel Institute) membagi stainless steel atas martensitic, ferrisitic, dan austenititc stainless steel yang dibedakan atas beberapa seri. ${ }^{3}$ Stainless steel $316 \mathrm{~L}$ adalah salah satu varian molybdenum alloy austenitic stainless steel dengan komposisi rendah karbon yang digunakan di dalam berbagai industri dengan kebutuhan spesifikasi logam yang tahan terhadap korosi. Pada umumnya stainless steel jenis ini digunakan pada: industri kimia dan petrokimia; instrumen industri pengolahan kertas; instrumen industri tekstil; instrumen industri makanan dan minuman; instrumen industri farmasi; instrumen medis; industri pipa air. ${ }^{4}$ Tipe 316 L merupakan salah satu tipe stainless steel yang dipakai di dalam pembuatan implant. ${ }^{3}$ Material tersebut memiliki komposisi karbon rendah sehingga dapat meningkatkan ketahanan terhadap korosi sama halnya dengan kandungan molybdenum pada material tersebut. ${ }^{4}$ Komposisi material tersebut secara lengkap dapat dilihat pada Tabel 1.

Tabel 1. Tabel komposisi kimia Stainless steel alloy 316 L/4404. ${ }^{4}$

\begin{tabular}{cc}
\hline Komponen & Persentase (\%) \\
\hline $\mathrm{C}$ & 0,02 \\
$\mathrm{Cr}$ & 17,2 \\
$\mathrm{Ni}$ & 10,1 \\
$\mathrm{Mo}$ & 2,1 \\
$\mathrm{Fe}$ & $<70$ \\
\hline
\end{tabular}

SS 316 L/4404 memiliki ketahanan terhadap korosi di dalam larutan organik bebas halogen dan senyawa anorganik pada rentang suhu dan konsentrasi yang luas. ${ }^{4}$ Stainless steel jarang dipakai sebagai bahan implan karena potensi alergi nikel yang terkandung di dalam Stainless steel karena adanya potensi korosi pit ataupun korosi crevice. Produk korosi pada stainless steel seperti besi, kromium, nikel dan molybdenum dapat ditransfer ke tubuh dan berpotensi menimbulkan respon imun yang tidak diinginkan. ${ }^{3}$ 
Kobalt kromium (CoCr) adalah cobalt-based alloy dengan campuran chromium. ${ }^{3}$ Paduan (Alloy) kobalt kromium ( $\mathrm{CoCr}$ ) merupakan salah satu biometal yang paling banyak digunakan sebagai implan permanen. ${ }^{12}$ Kepadatan (density) dari logam campur kobalt kromium adalah sekitar 8-9 $\mathrm{gram} / \mathrm{cm}^{3}$ atau setengah dari kepadatan logam campur emas dan menyebakan logam campur ini relatif sangat ringan. ${ }^{13,14}$ Remanium GM 800 merupakan salah satu jenis alloy kobalt kromium yang sering dipakai sebagai logam tuang dalam pembuatan gigi tiruan sebagian dengan kelebihan memiliki resistensi terhadap fraktur yang tinggi serta modulus elastisitas yang tinggi. Komposisi remanium GM 800 dapat dilihat pada Tabel $2 .{ }^{6}$

Tabel 2. Tabel komposisi kimia kobalt kromium Remanium GM $800 .^{6}$

\begin{tabular}{cc}
\hline Komponen & Persentase (\%) \\
\hline Co & 60,5 \\
Cr & 28 \\
W & 9 \\
Si & 1,5 \\
\hline
\end{tabular}

Secara alamiah, hampir semua logam akan mengalami proses korosi sebagai suatu reaksi elektrokimia dalam rangka mencapai kesetimbangan termodinamika. Efek yang kurang menguntungkan dari proses korosi adalah terlepasnya ion-ion logam. ${ }^{7}$ Biokompatibilitas berhubungan dengan kemampuan material untuk melakukan suatu fungsi. Kemampuan untuk melakukan dan melanjutkan fungsi material tidak hanya tergantung dari interaksi jaringan tetapi juga menyangkut sifat mekanis dan fisik dari material. ${ }^{15}$ Biokompatibilitas menggambarkan kemampuan suatu material untuk melakukan respon host yang tepat seperti yang diharapkan. Pada kenyataannya, relevansi respon host sangat penting. ${ }^{16}$ Penelitian ini bertujuan untuk mengetahui konsentrasi tepat yang digunakan untuk uji GPMT sebagai uji hipersensitivitas tipe IV pada logam stainless steel 316L dan kobalt kromium GM-800.

\section{METODE PENELITIAN}

Penelitian yang dilakukan merupakan penelitian laboratoris quasi eksperimental. Subjek penelitian adalah kobalt kromium Remanium GM $800^{\circledR}$ (Dentaurum) dan stainless steel $316 \mathrm{~L}$ (Outokumpu). Hewan coba yang digunakan adalah marmut dengan jenis kelamin betina yang sedang tidak hamil. Penelitian sudah dinyatakan layak untuk dilakukan sesuai dengan surat ijin kelayakan etik diperoleh dari Komisi Etik Penelitian Kedokteran dan Kesehatan Fakultas Kedokteran Universitas Gadjah Mada Yogyakarta (Medical and Health Research Ethics Comittee (MHREC), Ministry of Education and Culture Faculty of Medicine, Gadjah Mada University) nomor Ref: KE/FK/929/EC.

Bahan penelitian yang dipakai adalah pasta stainless steel atau kobalt kromium konsentrasi $5 \%, 10 \%, 20 \%, 40 \%$, dan $80 \%$. Serbuk kobalt kromium dan stainless steel ditimbang seberat 50 mg (ISO 10993:5, 2012; ISO 10993:12, 2012). Sediaan tersebut ditimbang kembali dan dipisah menjadi beberapa kelompok tunggal menyesuaikan konsentrasi yang diinginkan dan dibungkus kertas. Sterilisasi dilakukan dengan memasukkan sediaan tersebut ke dalam autoclave selama 15 menit dengan tekanan $15 \mathrm{~Pa}$. Pasta logam kobalt kromium konsentrasi $5 \%$ dibuat dengan mencampurkan 2,5 mg serbuk logam ditambahkan vaselin album hingga $50 \mathrm{mg}$. Pasta konsentrasi 10\% dibuat dengan mencampurkan $5 \mathrm{mg}$ serbuk logam ditambahkan vaselin album hingga $50 \mathrm{mg}$. Pasta konsentrasi $20 \%$ dibuat dengan mencampurkan 10 mg serbuk logam dtambahkan vaselin album hingga $50 \mathrm{mg}$. Pasta konsentrasi $40 \%$ dibuat dengan mencampurkan $20 \mathrm{mg}$ serbuk logam ditambahkan vaselin album hingga $50 \mathrm{mg}$. Pasta konsentrasi $80 \%$ dibuat dengan mencampurkan $40 \mathrm{mg}$ serbuk logam ditambahkan vaselin album hingga $50 \mathrm{mg}$.

Marmut yang akan dipakai sebagai hewan coba diaklimatisasi selama 5 hari di dalam kandang. Marmut dibagi menjadi tiga kelompok yaitu kelompok kontrol, perlakuan stainless steel dan perlakuan kobalt kromium masing-masing sejumlah 3 ekor. Patch berisi pasta stainless steel atau kobalt kromium dengan konsentrasi $5 \%, 10 \%$, $20 \%$, 40\%, dan $80 \%$ untuk ditempelkan selama 24 jam pada hewan coba. Marmut diamati 24 jam setelah pelepasan patch dengan melakukan skoring eritema dan oedema dengan bantuan lampu 
cahaya. Ulangi skoring setelah 24 jam skoring pertama. Tiga jam setelah pengamatan pertama, area uji dilakukan pencukuran kembali dengan alat cukur elektrik dan pembersihan sisa sisa bahan uji. Pengamatan dilakukan dengan melakukan skoring keparahan reaksi sensitisasi sesuai dengan skala Magnusson dan Kligman pada Tabel 3.

Tabel 3. Skala Magnusson dan Kligman

\begin{tabular}{cc}
\hline Reaksi uji & Skor \\
\hline Tidak terdapat perubahan & 0 \\
Eritema kecil atau bercak eritema & 1 \\
Eritema sedang dan berkumpul & 2 \\
Eritema berat/pekat dan bengkak & 3 \\
\hline
\end{tabular}

Konsentrasi tertinggi yang tidak menyebabkan eritema kuat (skor 2) dapat digunakan pada tahap induksi penelitian lanjutan uji hipersensitivitas tipe IV. Konsentrasi tertinggi yang tidak menyebabkan eritema (skor 0) dapat digunakan pada tahap challenge penelitian lanjutan uji hipersensitivitas tipe IV.

\section{HASIL PENELITIAN}

Penelitian dilakukan untuk mendapatkan konsentrasi tepat yang akan digunakan untuk penelitian GPMT untuk mengetahui keamanan material tersebut. Pada penelitian ini didapatkan data ordinal berupa tingkat keparahan eritema maupun edema. Kelompok marmut dengan perlakuan kobalt kromium GM-800 dan stainless steel $316 \mathrm{~L}$ konsentrasi 5\% tidak menyebabkan eritema maupun edema (skor 0 ), sedangkan pada konsentrasi $10 \%$ terdapat bercak eritema pada punggung marmut (skor 1). Aplikasi kobalt kromium GM-800 serta stainless steel 316 L konsentrasi $20 \%$ dan $40 \%$ terdapat eritema sedang dan mengumpul (skor 2). Kobalt kromium GM-800 serta stainless steel $316 \mathrm{~L}$ konsentrasi $80 \%$ menyebabkan eritema pekat dan edema pada punggung marmut (skor 3). Gambaran klinis masing- masing skor dapat dilihat pada Gambar 1 berikut.

\section{PEMBAHASAN}

Tenaga kesehatan seperti dokter gigi dan pasien sering terpapar dan berkontak langsung dengan material dental. Material yang digunakan dapat berbahaya bagi dokter gigi, pasien maupun perawat gigi, oleh karena itu diperlukan suatu pengujian apakah material tersebut aman digunakan sebagai material kesehatan. Salah satu pengujian yang perlu diuji adalah untuk menguji apakah material tersebut dapat menimbulkan alergi melalui uji Guinea Pig Maximization Test (GPMT). ${ }^{16}$

Guinea Pig Maximization Test (GPMT) merupakan salah satu uji sensitisasi (hipersensitivitas tipe IV) yang menggunakan marmut sebagai hewan coba. ${ }^{11}$ Penelitian dengan metode GPMT memerlukan uji awalan yang berfungsi untuk mengetahui konsentrasi yang tepat pada masing-masing material untuk dapat diuji pada tahap berikutnya. Uji yang dilakukan pada penelitian ini menggunakan logam stainless steel $316 \mathrm{~L}$ dan kobalt kromium remanium GM-800. Pada penelitian, aplikasi patch SS $316 \mathrm{~L}$ dan kobalt kromium Remanium GM-800 konsentrasi 5\% tidak terjadi eritema maupun edema pada punggung marmut sehingga menurut Magnusson dan Kligman dapat digunakan sebagai konsentrasi yang tepat untuk dipakai pada tahap challenge, sedangkan aplikasi patch konsentrasi 10\% terjadi bercak eritema pada punggung marmut. Aplikasi patch konsentrasi $40 \%$ terjadi eritema sedang dan berkumpul pada punggung marmut.

Eritema merupakan penampakan klinis dari proses vasodilatasi pembuluh darah yang menyebabkan peningkatan tekanan pada kapiler darah serta bertambahnya permeabilitas pembuluh darah. ${ }^{17}$ Eritema dan indurasi yang terjadi merupakan manifestasi terjadinya inflamasi pada kulit akibat dari proses respon imunitas akibat paparan antigen. Empat jam setelah paparan antigen, neutrofil terakumulasi disekitar venula pada area paparan. Dua belas jam setelah paparan, sel limfosit $\mathrm{T}$ dan monosit akan terorganisasi di sekitar venula. Sel sel endotel yang mengelilingi venula akan membesar dan meningkatkan jumlah plasma yang masuk ke jaringan. Fibrinogen akan terdeposisi ke dalam jaringan dan berubah menjadi fibrin. Deposisi fibrin, akumulasi sel limfosit T dan monosit ke dalam jaringan menyebabkan indurasi serta pembengkakan pada jaringan kulit. ${ }^{18}$ Manifestasi berupa eritema, pembengkakan serta indurasi pada kulit tersebut merupakan urutan kejadian yang terjadi pada hipersensitivitas tipe IV. 


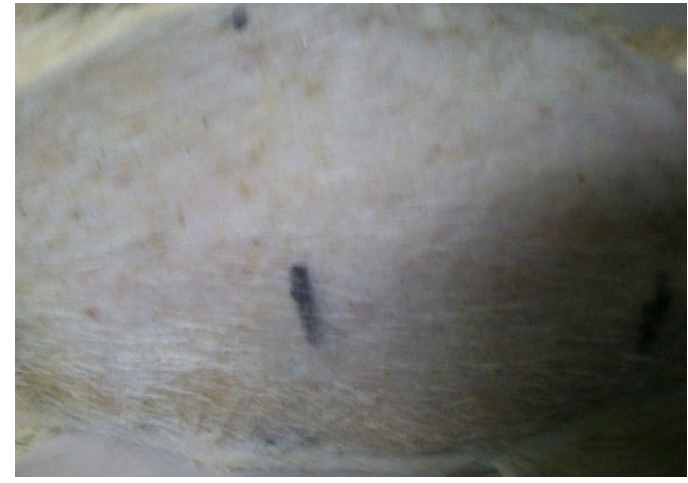

(A)

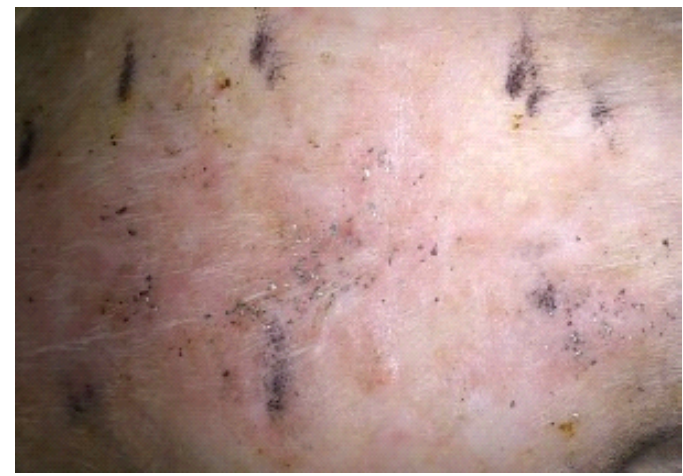

(C)

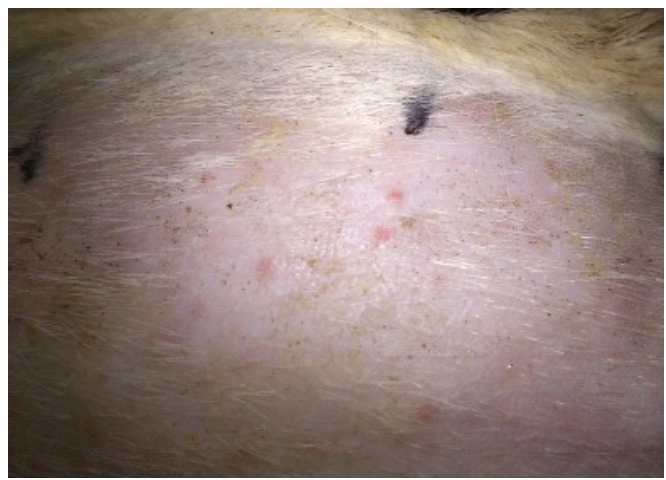

(B)

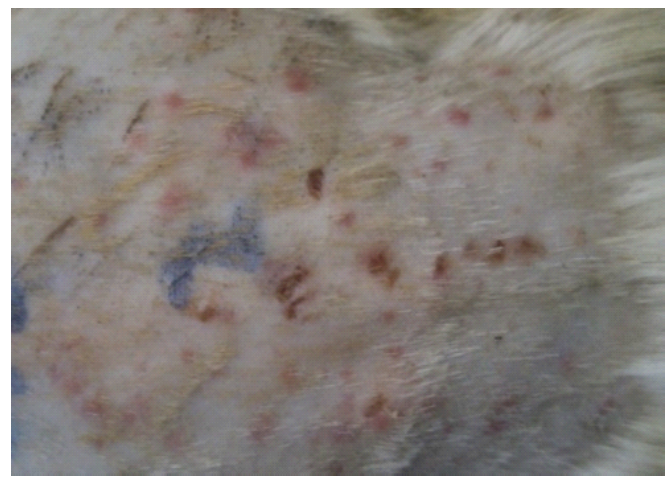

(D)

Gambar 1. Gambaran klinis pada area uji (A) Skala 0 (B) Skala 1 (C) Skala 2 (D) Skala 3

Hipersensitivitas adalah istilah yang digunakan saat respon imun menghasilkan reaksi yang tidak diinginkan bahkan membahayakan hidup seseorang. ${ }^{19}$ Hipersensitivitas tipe IV terjadi 1-3 hari setelah terpapar oleh antigen. Reaksi terjadi dalam beberapa fase. Fase pertama melibatkan proses masuk, prosesing dan presentasi antigen oleh molekul HLA klas II. Peptida akan dipresentasikan oleh makrofag dan sel dendritik pada lokasi paparan dan menstimulasi antigen-spesifik memory T-cells meninggalkan aliran darah menuju ke jaringan. Fase kedua antigen-spesifik memory T-cells yang diproduksi saat paparan pertama oleh antigen akan bermigrasi ke area terpapar dan akan teraktivasi. $T$ helper $1\left(\mathrm{~T}_{\mathrm{H}} 1\right)$ teraktivasi akan melepas mediator yang akan mengaktivasi sel-sel endotelial sehingga merekrut infiltrat sel inflamatori yang didominasi oleh makrofag dan menyebabkan akumulasi cairan serta protein. ${ }^{20}$

Pada reaksi hipersensitivitas, pruritus dan skin rash disebabkan $C D 8^{+}$cytotoxic cells yang menyerang sel kulit yang menganggap material tersebut sebagai antigen benda asing. Indurasi kulit terjadi akibat $C D 4^{+}$helper $T$ cells dan makrofag yang bermigrasi menuju ke tempat paparan antigen. ${ }^{19}$ Molekul kecil berperan sebagai hapten yang masuk ke kulit, berikatan dengan protein tubuh menjadi bentuk antigen utuh yang dapat memicu sel-sel imun. Makrofag akan menelan antigen, memproses antigen tersebut dan mempresentasikan antigen sebagai epitop pada permukaan protein class II MHC. Sel T helper (Th-1) aktif dan memproduksi interferon gamma yang akan mengaktifkan makrofag. Paparan material yang sama pada beberapa waktu kemudian menyebabkan eritema, gatal, vesikel, krusta atau neksrosis pada kulit dalam waktu 12-48 jam akibat dari serangan cytotoxic T cell. ${ }^{19}$

Berbagai sitokin berperan dalam terjadinya reaksi hipersensitivitas tipe IV. IFN- $\gamma$ merupakan salah satu sitokin yang terpenting dalam hipersensitiitas tipe IV, sitokin tersebut merupakan aktivator makrofag yang sangat poten sehingga aktif dan mengeluarkan molekul klas II MHC pada permukaannya sehingga meningkatkan kemampuan penyajian antigen. Makrofag tersebut 
juga akan mensekresi PDGF dan TGF- $\alpha$ yang merangsang proliferasi fibroblas dan sintesis kolagen, sehingga apabila aktivasi makrofag berlangsung terus menerus akan terjadi fibrosis. IL-2 menyebabkan proliferasi sel $\mathrm{T}$ yang telah terakumulasi pada area hipersensitif termasuk 10\% dari sel $\mathrm{CD}^{4+}$ yang spesifik terhadap antigen dan sebagian besar sel $\mathrm{T}$ naive non spesifik yang akan menyerang antigen. TNF dan limfotoksin berfungsi dalam 3 fungsi yaitu (1) akan meningkatkan sekresi nitrit oksida dan prostasiklin yang membantu peningkatan aliran darah melalui vasodilatasi lokal. (2) meningkatnya pengeluaran selektin-E yang merupakan molekul adesi yang meningkatkan perlekatan sel mononuklear seperti makrofag. (3) induksi dan sekresi faktor kemotaksis seperti IL8. Perubahan-perubahan yang terjadi akibat TNF dan limfotoksin secara berkesinambungan akan memudahkan keluarnya limfosit dan monosit pada lokasi terjadinya hipersensitivitas tipe IV. ${ }^{10}$

Hasil penelitian implantasi kobalt kromium GM-800 menyatakan bahwa inflamasi yang terjadi setelah implantasi terjadi akibat reaksi benda asing, bukan akibat ion-ion logam yang terlepas dari logam kobalt kromium. ${ }^{21}$ Pelepasan ion logam sangat berkaitan dengan kontak antara logam campur dan cairan tubuh. Pelepasan ion nikel dan besi dari logam campur stainless steel 1000x lebih rendah dibandingkan dengan sediaan logam murni. ${ }^{22}$

\section{KESIMPULAN}

Kesimpulan penelitian ini yaitu konsentrasi $5 \%$ merupakan konsentrasi yang direkomendasikan untuk logam stainless steel $316 \mathrm{~L}$ dan kobalt kromium GM-800 dapat digunakan sebagai konsentrasi pada tahap challenge penelitian GPMT. Konsentrasi $40 \%$ merupakan konsentrasi yang direkomendasikan untuk logam stainless steel 316 $\mathrm{L}$ dan kobalt kromium GM-800 dapat digunakan pada tahap induksi intradermal GPMT.

\section{UCAPAN TERIMAKASIH}

Ucapan terima kasih diberikan kepada Prof. Dr. drg. Widowati Siswomihardjo selaku pimpinan proyek penelitian "Uji Biokompatibilitas Material Stent" yang merupakan payung besar penelitian ini. Laboran laboratorium Farmakologi FK yang telah banyak membantu dalam proses penelitian ini. Terimakasih saya tujukan kepada Dinas Pendidikan Tinggi yang telah memberikan dukungan finansial bagi keberlangsungan penelitian ini.

\section{DAFTAR PUSTAKA}

1. Booth PW, Eppley BL, Schmelzeisen R. Maxillofacial trauma and esthetic facial reconstruction. Edinburg: Churchill Livingstone; 2003. 144 - 147.

2. Ferracane JL. Material in dentistry: principles and applications. $2^{\text {nd }}$ ed. Baltimore: Lippincott Williams \&Willkins; 2001. $282-283$.

3. Anusavice KJ, Shen CH, Rawls R. Phillip's science of dental materials. St. Louis: Elsevier Saunders; 2013. 638.

4. Outokumpu. Handbook of Stainless steel. Sweden: Outokumpu; 2015. www.outokumpu. com/sitecollectiondocuments/outokumpustainless-steel-handbook.pdf diunduh pada 20/12/2015.

5. Keegan GM, Learmonth ID, Case CP. A systematic comparison of the actual, potential, and theoretical health effects of cobalt and chromium exposures from industry and surgical implants. Crit Rev Toxicol. 2008; 38(8): $645-674$.

6. Dentaurum. Remanium GM 800 Factsheet. Germany: Dentaurum; 2008. HYPERLINK "https://www.dentaurum.de/eng/remaniumgm-800-17034.aspx" https://www. dentaurum.de/eng/remanium-gm-800-17034. aspx diunduh pada 20/12/2015.

7. Geurtsen W. Biocompatibility of dental casting alloys. CritRev of Oral Biol Med. 2002; 13(1): 71-74.

8. Behl B, Papageorgiou I, Browna C, Hall R, Tipper JL, Fisher J, Ingham E. Biological effects of cobalt-chromium nanoparticles and ions on dural fibroblasts and dural epithelial cells. Biomaterials. 2013; 34: 3547 - 3558. 
9. Richard FW, Paul JU. A practical Guide to ISO 10993-10: Sensitization. International Organization for Standardization (ISO); 2009.

10. Kumar V, Cotran RS, Robbins SL. Buku Ajar Ptaologi Robbins (terj.), Jakarta: Penerbit Buku Kedokteran EGC; 2014. 132.

11. International Organization for Standardization. Biological evaluation of medical devices Part 10: Tests for irritation and skin sensitization. Geneva; 2010. 15 - 19.

12. Ivanova EP, Bazaka K, Crawford RJ. Metallic biomaterials: types and advanced applications dalam new functional biomaterials for medicine and healthcare, 1st Ed. St. Louis: Saunders Elsevier; 2014.

13. Hjalmarsson L. On cobalt-chrome frameworks in implant dentistry. Goeteborg: Goeteborg University; 2009.

14. Nouri A. Hodson PD, Wen C. Biomimetic porous titanium scafolds for orthopaedics and dental application. China: Intech; 2010, ISBN 978-953-307-025-4.

15. Doherty P. Inflammation, Carcinogenicity, and Hypersensitivity, inNarayan, R. (ed.): Biomedical Materials. New York: Springer Science; 2009. $210-212$.
16. Schmalz G, Arenholt-Bindslev D. Biocompatibility of dental materials. Berlin: Springer; 2009. 1 - 15.

17. Corwin EJ. Buku Saku Patofisisologi Corwin (terj.). Jakarta: Penerbit Buku Kedokteran EGC; 2009.

18. Abbas AK, Lichtman AH, Pillai S. Cellular and Molelecular Immunology. Philadelphia: Elsevier; 2012.

19. Levinson S, Warren M. Review of medical microbiology and immunologi. $9^{\text {th }}$ ed. New york: McGraw-Hill Lange; 2006. 410, 411, 459.

20. Parham P. The Immune System. $2^{\text {nd }}$ ed. New York: Garland Science; 2005. 320 - 339.

21. Alhasyimi $A A$, Sunarintyas $S$, Soesatyo MHNE. Pengaruh implantasi subkutan logam kobalt kromium sebagai bahan alternatif mini screw orthodontics terhadap reaksi jaringan kelinci albino. Maj Ked Gi Ind. 2015; 1(1): 94 101.

22. Santonen $\mathrm{T}$, Stockmann-Juvala $\mathrm{H}$, Zitting $\mathrm{A}$. Review on Toxicity of Stainless Steel. Helsinki; 2010. 1 - 80 . 